\title{
Further Arguments against 4-methylimidazole as Causal Factor in Ammoniated Forage Toxicosis: Experimental Seed-hay Poisoning in Young Lambs
}

4-methylimidazole (4-MeI) is up to now the main tremorogenic poison known to be present in ammoniated roughages. The concentration of 4-MeI is widely used as an indicator of the potential toxicity of individual batches of ammoniated straw and hay.

4-MeI given orally or intravenously to ruminants does indeed produce a disease state similar to the naturally occuring ammoniated forage poisoning (Morgan \& Edwards 1986, Nielsen et al. 1986, Fairbrother \& Essig 1987, Friis Kristensen et al. 1991). However, the amount of 4-MeI necessary to produce symptoms has been high compared with what is commonly found in samples of forage from poisoning cases. This has led to a continuous discussion on whether 4-MeI is the real agent responsible for the naturally occuring disease. One group of authors (Weiss et al. 1986) found indications that a quite different, yet unidentified substance may be responsible. Other authors (Friis Kristensen et al. 1991) confine themselves to the statement "..that 4-MeI alone cannot cause the "crazy cow" syndrome..".

Previous studies have shown very large variations of 4-MeI content in different samples from the same bale of ammoniated seed hay, depending on where they are taken from within the bale (Randby \& Langseth 1990). Concentrations in seed hay from the part of the bale lying on top during $\mathrm{NH}_{3}$ treatment may be as much as 8 times higher than in samples taken from the bottom level. This experience led us to undertake a study where sheep were fed on ammoniated seed hay taken exclusively from the upper parts of the bales. In this way we achieved a level of 4-MeI that, with 1 day's exception, stayed above 100 $\mathrm{mg} / \mathrm{kg}$ dry matter (DM) in the seed hay fed throughout the 4-week experimental period. In the crucial first week of the experiment, we achieved a steady level of 121 - $158 \mathrm{mg} \mathrm{4-}$ $\mathrm{MeI} / \mathrm{kg} \mathrm{DM}$. Because it is well established that newborn, sucking ruminants may be poisoned through the milk without their mothers being affected (Weiss et al. 1986, Fairbrother \& Essig 1987), we used 3 ewes with young, sucking lambs as experimental animals. 4-MeI concentrations were measured frequently in the feed, in the plasma of ewes and lambs, and in the ewes' milk.

The 4-MeI analyses were done by a modified version of a method described by Thomsen \& Willumsen (1981). The dried seed hay samples were ground and extracted with phosphate buffer, $\mathrm{pH}$ 6.0, while phosphate buffer was added directly to the milk of plasma samples. The 4-MeI was then extracted into chloroform by ion-pair extraction with di(2-ethylhexyl)-phosphate (DEHPA), and extracted back into $0.1 \mathrm{M}$ phosphoric acid. Analyses were done by HPLC with reverse-phase ionpair chromatography. The analytical column 
Table 1: Concentration of 4-methylimidazole $(\mu \mathrm{g} / \mathrm{ml})$ in samples of plasma from ewes and lambs and milk from ewes through the first 7 days of the experiment with toxic ammoniated seed hay.

\begin{tabular}{lcrccccc}
\hline & & \multicolumn{7}{c}{ Experimental Day } \\
\cline { 3 - 8 } Sample & & 2 & 3 & 4 & 5 & 6 & 7 \\
\hline Eve A & Plasma & 0.04 & 0.05 & 0.06 & 0.05 & 0.06 & 0.07 \\
& Milk & 0.22 & 0.27 & 0.32 & 0.28 & 0.25 & 0.47 \\
Lamb 1 & Plasma & $<0.01$ & - & - & 0.01 & - & $<0.01$ \\
& & & & & & & \\
Ewe B & Plasma & 0.05 & 0.08 & 0.05 & 0.04 & 0.06 & 0.07 \\
& Milk & 0.23 & 0.41 & 0.12 & 0.21 & 1.46 & 2.27 \\
Lamb 2 & Plasma & $<0.01$ & $<0.01(\mathrm{~S})$ & & & & \\
& & & & & & & \\
Ewe C & Plasma & 0.04 & 0.01 & 0.03 & 0.03 & 0.02 & 0.02 \\
& Milk & 0.16 & 0.11 & 0.09 & 0.11 & 0.19 & 0.13 \\
Lamb 3 & Plasma & 0.01 & - & - & $0.01(\mathrm{~S})$ & & \\
Lamb 4 & Plasma & $<0.01$ & - & - & 0.01 & $0.01(\mathrm{~S})$ & \\
\hline
\end{tabular}

(S) means that the sample is taken immediately after the occurrence of active symptoms.

was a Nucleosil C8, $125 \mathrm{x} 4 \mathrm{~mm}$ I.D. column with a $50 \mathrm{~mm}$ guard column, dry packed with LC-8 pellicular packing, $40 \mu \mathrm{m}$ (Supelco). The mobile phase consisted of methanol- $0.05 \mathrm{M}$ potassium dihydrogen phosphate buffer $\mathrm{pH}$ 5.3 (32.5 + 67.5), containing 0.005 sodium dodecane-1-sulphonate. A UV spectrophotometer set at $213 \mathrm{~nm}$ was used as detector. Within 6 days from the start of the experiment, three of the ewes' four lambs showed classical, severe symptoms of ammoniated forage poisoning, and were euthanized for animal welfare reasons. These 3 lambs were 14 - 17 days old and weighed $7.4-8.5 \mathrm{~kg}$ at the time they showed symptoms. The last, somewhat older lamb (23 days $/ 12 \mathrm{~kg}$ at start of exp.) did show signs of agitation from time to time, but did not develop full-scale poisoning. In the ewes we observed no symptoms of poisoning.

Plasma samples from the lambs were also analyzed for lactate, calcium, magnesium, bilirubin, creatinine, urea, creatine kinase $(\mathrm{CK})$ activity, ALAT and ASAT. In agreement with other authors (Weiss et al. 1986), we observed increased lactate levels, but only after active seizures. A correlated increase in plasma CK, while other biochemical parameters remained normal, suggests that this lactate rise was secondary to muscular tremors. Autopsy of the lambs revealed no macroscopical lesions, and no evident histological changes could be demonstrated in the brains.

Levels of 4-MeI found in ewe plasma, ewe's milk and in plasma of the lambs during the first week are presented in Table 1 . We have no obvious explanation for the higher levels found in the milk of ewe B on day $6 \& 7$. Similar levels were not revealed throughout the experimental period. Accidental contamination of the milk by seed hay fragments during milking cannot be totally excluded.

Judging from published studies on the pharmacokinetics of 4-MeI in ruminants ( $\mathrm{Ka}$ rangwa et al. 1990, Nielsen et al. 1993) and from feeding experiments with heifers (Friis Kristensen et al. 1991), our observed levels of 4-MeI in ewe plasma compared with the levels in the feed are lower than expected. This might be due to different degrees of rumen 
metabolism of 4-MeI under different conditions. The levels of 4-MeI in ewe's milk compared with plasma are, except for ewe B on days 6 and 7, in good agreement with published data (Friis Kristensen et al. 1991). Assuming the ewes' milk to be their dominant feed at this age, the 4-MeI levels in lamb plasma also seem reasonable.

However, the resultant plasma levels in our lambs are indeed very low, taken into account that 3 of these lambs showed severe symptoms of poisoning. Reported plasma levels in experimental 4-MeI poisoning of heifers are not lower than $4 \mu \mathrm{g} / \mathrm{ml}$ (Friis Kristensen et al. 1991), or more than 400 times higher than the levels observed in our lambs. In feeding experiments with ammoniated hay to heifers Friis Kristensen et al. (1991) reported plasma levels of $0.09-0.70 \mu \mathrm{g} / \mathrm{ml}$ in poisoned animals. These levels, being on average 15 times below levels observed in experimental 4-MeI poisoning, were part of the basis for these authors' conclusion that 4-MeI cannot alone be responsible for ammoniated forage poisoning. The plasma levels found in our lambs do, in our opinion, further reduce the possibility of 4-MeI being causative to the symptoms. Thus, our results strongly support the idea of a yet unknown substance as the main source of toxicity.

Certainly, our results also confirm the higher vulnerability of newborn ruminants to ammoniated forage toxicosis, compared with older animals. If, however, 4-MeI should be the causal agent to the symptoms we observed, the sensitivity of newborn lambs to 4MeI must be extreme. Fairbrother \& Essig (1987) did not find any such effect in young calves.

\section{Acknowledgements}

We are grateful to Ottar Kjus in A/S Norsk Fôrkonservering for providing the ammoniated seed hay bales and to Anneli Høiden Skogstad and Patricia A. Engen at the Laboratory Animal Department of the Norwegian College of Veterinary Medicine for excellent care of the animals. The biochemical analyses were carried out by Dept. of large animal diseases and Dept. of biochemistry at Norw. Coll. of Vet. Med. and the pathological examination by Dept. of pathology, National Veterinary Institute.

Tore Sivertsen, Wenche Langseth and Elisabet Mo Department of Toxicology and Chemistry, National Veterinary Institute.

\section{Kristian Ingebrigtsen}

Department of Pharmacology, Microbiology and Food Hygiene, Norwegian College of Veterinary Medicine, Oslo, Norway.

\section{References}

Fairbrother TE, Essig MW: Effects of 4-methylimidazole in young calves. Vet. Hum. Toxicol. 1987, 29, 312-315.

Friis Kristensen V, Enevoldsen $C$, Witt $N$, Nielsen $P$, Kraul I, Friis C, Krogh Nielsen T, Wolstrup C: Forgiftning forårsaget af ammoniakbehandlet grovfoder (Toxicity of ammoniated roughages). 17. beretning, Fællesudvalget for Statens Planteavls- og Husdyrbrugsfors $\varnothing \mathrm{g}$, Copenhagen 1991, 41p.

Karangwa E, Mitchell GE, Tucker RE: Pharmacokinetics of 4-methylimidazole in sheep. J. Anim. Sci. 1990, 68, 3277-3284.

Morgan SE, Edwards WC: Bovine Bonkers: New terminology for an old problem. A review of toxicity problems associated with ammoniated feeds. Vet.Hum.Toxicol. 1986, 28, 16-18.

Nielsen P, Friis C, Kraul I, Olsen CE: Disposition of 4-methylimidazole in goats and heifers. Res. vet. Sc. 1993, 54, 72-79.

Nielsen TK, Wolstrup C, Witt N, Friis Kristensen V, Kraul I: 4-methylimidazole in ammoniated roughage. Preliminary investigations. Proceedings, 6th Intern. Conf. on Prod. Dis. in Farm Anim., Belfast Sept. 1986.

Randby $\AA$, Langseth $W$ : Ammoniakkbehandling av halm. Betingelser for dannelse av 4-metylimidazol (Ammonia treatment of straw. Conditions for formation of 4-methylimidazole). Rapport fra Hellerud fors $\varnothing \mathrm{ks}-$ og eliteavlsgard, $\mathrm{Nr} 3$, 1990, 26 pp. 
Thomsen M, Willumsen D: Quantitative ion-pair extraction of 4(5)methylimidazole from caramel colour and its determination by reversed-phase ion-pair liquid chromatography. J. Chromatogr. 1981, 211, 213-221.
Weiss WP, Conrad HR, Martin CM, Cross RF, Shockey WL: Etiology of ammoniated hay toxicosis. J. Anim. Sci. 1986, 63, 525-532.

(Received March 9, 1993; accepted June 1, 1993).

Reprints may be requested from: T. Sivertsen, Department of Toxicology and Chemistry, National Veterinary Institute, P.O. Box 8156, N-0033 Oslo, Norway. 